Annals of Tropical Research 29[1]:14-25(2007)

(c) LSU, Leyte, Philippines

\title{
Tomato fruit parthenocarpy and yield increase in response to chlorophenoxyacetic acid
}

\author{
Rosalina D. Poliquit' and Misael T. Diputado, Jr. ${ }^{2}$ \\ ${ }^{1}$ Department of Biological Sciences, College of Arts and Sciences, Leyte State \\ University, Baybay, Leyte 6521-A, Philippines; \\ ${ }^{2}$ Department of Horticulture, College of Agriculture, Leyte State University, \\ Baybay, Leyte 6521-A Philippines
}

\begin{abstract}
An experiment was conducted to evaluate the influence of rate and time of application of chlorophenoxyacetic acid (CPA) on the fruit set, yield and quality of tomato (variety, Improved Pope) The application of CPA enhanced fruit set, reduced the number of days to fruit maturity and consequently increased the yield and yield components of tomato. The optimum concentration of the chemical was $75 \mathrm{pm}$. It was more effective when applied during anthesis than one week after anthesis.

CPA application regardless of concentration caused the production of parthenocarpic fruits. It did not significantly affect fruit quality in terms of peel color development, firmness, visual quality rating and weight loss.
\end{abstract}

Keywords: chlorophenoxyacetic acid, fruit set, plant growth regulator, parthenocarpy, tomato

Correspondence: M. T. Diputado Jr. Present Address: Department of Horticulture, College of Agriculture, Leyte State University, Visca, Baybay, Leyte 6521-A, Philippines. Tel. No. (053) 335-2628; Fax No. (053) 563-7051

DOI: $10.32945 /$ atr2912.2007 


\section{INTRODUCTION}

Tomato (Lycopersicon esculentum Mill) is one of the most important vegetables grown throughout the world. In the Philippines, it ranks first in terms of area of production among the major vegetable crops (Philippine Statistical Yearbook, 1999). It is a profitable cash crop to small farmers.

The tomato fruit can be eaten fresh or cooked and can be processed into pastes, catsups, sauces, soup, juice, pickles and many other products. Aside from its being an excellent source of vitamins A and C (AVRDC, 1991), it also contains high amounts of lycopene, a substance known to help the body fight against certain diseases (Stahl and Sies, 1996).

In the tropics, tomato production is beset by many problems, the most important of which is low fruit set at high temperatures, particularly during nighttime. Fruit set is one of the key components determining the final yield in tomatoes (Picken, 1984). The biggest challenge therefore for tomato production is how to improve fruit set during periods of high night temperature.

In recent years, the use of plant growth regulators has been the most promising alternative for improving fruit set in many crops (Weaver, 1972; Kuo et al., 1986). Auxins, in natural or synthetic forms have been successfully used to improve fruit set in a number of crops (AVRDC, 1995; del Rosario et al., 1977; Joseph and Peter,1980; Abit, 1981). Other PGR's that have been successfully used are gibberellins (Weaver, 1972; AVRDC, 1995) and cytokinins (Weaver, 1972; Arumin et al., 1985) However, the response of crops to application of plant growth regulators to improve fruit set varies with cultivars and locations. Most of the studies on the use of PGR's to improve fruit set in tomatoes were done in other countries and very limited studies have been conducted under local conditions.

This study was conducted to evaluate the influence of rates and timing of application of chlorophenoxyacetic acid (CPA) on fruit set, yield and fruit quality of tomato.

\section{MATERIALS AND METHODS}

\section{Land preparation}

An area of $361 \mathrm{~m}^{2}$ was plowed and harrowed to pulverize the soil clods and remove weeds. Plowing and harrowing were done two times at weekly 
interval. The area was divided into three blocks, each block consisting of 10 plots measuring 1.5 meters by 2.5 meters. Alleyways of 0.5 meters between plots and 1 meter between blocks were provided for ease in the management of the experiment.

\section{Seedling production and transplanting}

Improved Pope variety was used in this study. Seedlings were raised using the modified cellular method. Healthy and uniformly sized seedlings were transplanted into the prepared plots spaced at $0.4 \mathrm{~m}$ between hills and 1 $\mathrm{m}$ between rows.

\section{Experimental design and treatments}

The experiment was laid out in a split plot design with three replications. The treatments were as follows:

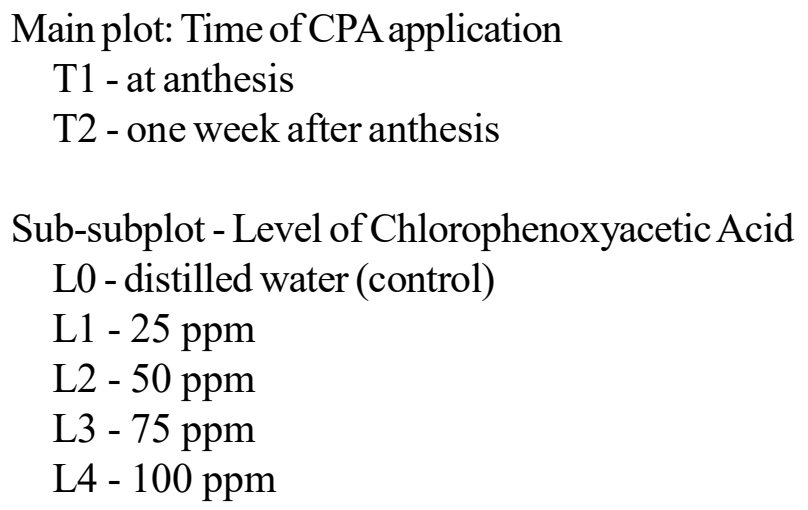

\section{Field cultural management practices}

Fertilizer application was based on the recommended rate of 90-120$60 \mathrm{~kg}$ per ha of $\mathrm{N}, \mathrm{P}_{2} \mathrm{O}_{5}, \mathrm{~K}_{2} \mathrm{O}$. At transplanting, 60-60-60 kg/ha of N, $\mathrm{P}_{2} \mathrm{O}_{5}$, $\mathrm{K}_{2} \mathrm{O}$ was applied. Four weeks after, $30-30 \mathrm{~kg} / \mathrm{ha} \mathrm{N}$ and $\mathrm{P}_{2} \mathrm{O}_{5}$ using urea and solophos, respectively, were sidedressed. Additional $30 \mathrm{~kg} \mathrm{P}_{2} \mathrm{O}_{5} /$ ha using solophos was applied at flowering.

Watering and handweeding were done as often as necessary. The plants were trellised three weeks after transplanting. Four wooden posts were installed per row and intertwined with wire. The stems were tied to the wire with plastic straw for additional support. 
The plants were sprayed with Lannate and Dithane M-45 following the recommended rates to control insect pests and fungal diseases, respectively. Spraying was done at weekly interval from one week after transplanting up to flowering stage.

Preparation and application of chlorophenoxyacetic acid (CPA)

Desired concentrations of chlorophenoxyacetic acid (CPA) solutions were prepared immediately before use with water as diluent and solvent. Tween 20 at $0.1 \%$ was added to the solution as surfactant. Previous studies by Kinet et al. (1978) showed that Tween 20 had no effect on inflorescence development and fruit set in tomato.

The treatment solutions were applied to each flower cluster individually using a hand sprayer with a fine spray nozzle at anthesis (when 2 to 3 flowers are open) or one week after anthesis. Spraying was done until the flowers were sufficiently wet.

\section{Harvesting}

The fruits were harvested at the mature green stage. Harvesting by hand was done once a week until the last harvest. Fruits were then sorted as either marketable or non-marketable. The non-marketable fruits were those which were very small in size (equatorial diameter less than $1 \mathrm{~cm}$ ), diseased or with physical damage.

\section{Sampling and data analysis}

Data on horticultural characteristics and yield parameters were taken from five sample plants while data on fruit characteristics from ten sample fruits per treatment during the second harvest.

\section{RESULTS AND DISCUSSION}

\section{Fruit set and fruit retention}

The application of CPA significantly increased percentage fruit set and fruit retention and shortened the period to fruit maturity of tomato relative to the control plants (Table 1). Plants applied with CPA at anthesis had significantly 
higher percentage fruit set compared to plants applied with CPA one week after anthesis. This was probably because at one week after anthesis, many of the flowers had already abscised.

The level of CPA application was found to significantly affect percent fruit set and retention and the number of days to fruit maturity (Table 1). Plants applied with CPA at 75-100 ppm had the highest percent fruit set which was more than 6 times compared to the control. The lower concentrations of 25$50 \mathrm{ppm}$ resulted to higher percent fruit set relative to the control, but were less effective compared to the aforementioned higher concentrations. Thus, as far as this parameter is concerned, the optimum concentration of CPA is $75 \mathrm{ppm}$. CPAapplication also significantly increased percent fruit retention relative to the control with the different concentrations having comparable effects. In addition, the application of CPA hastened the period to fruit maturity. Fruits of plants applied with high concentration of 75-100 ppm CPA matured the earliest followed by those applied with CPA at 25-100 ppm. The control plants took the longest time to fruit maturity. This result agrees with the findings of Weaver (1972). Goodwin (1978) speculated that exogenous auxin application might have triggered a rapid growth of the ovary as a result of increased cell division and enlargement allowing the fruit to attain full size and maturity earlier. The time of CPA application did not significantly affect the percent fruit retention and number of days to fruit maturity.

\section{Fruit characteristics}

Application ofCPA one week after anthesis resulted to the production of bigger and heavier fruits compared to application of the chemical at anthesis (Table 2). This was probably because fruits produced in plants applied one week after anthesis were fewer resulting to lesser competition for assimilates.

The fruits produced in the control plants were significantly lighter and smaller compared to those applied with the chemical (Table 2). The sizes and weights of the fruits were doubled by CPA application. In general, there were very little differences in the weight and size of tomato fruits applied with CPA at different concentrations.

Fruits produced from plants treated with CPA at all concentrations were seedless or parthenocarpic (Figure 1a) in contrast to the fruits produced by the control plants which all produced seeds (Figure 1b). The presence of seeds were only observed in the control plants. The time of application of CPA did not affect the number of seeds per fruit and the number of 


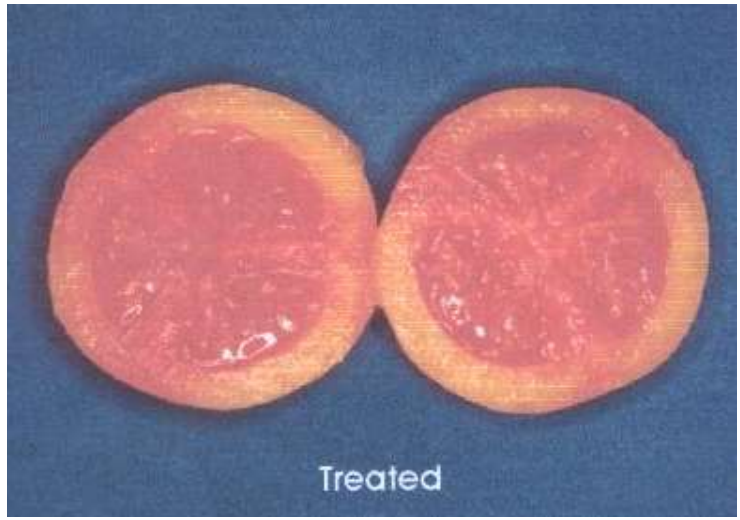

Figure 1a. Fruits treated with CPA

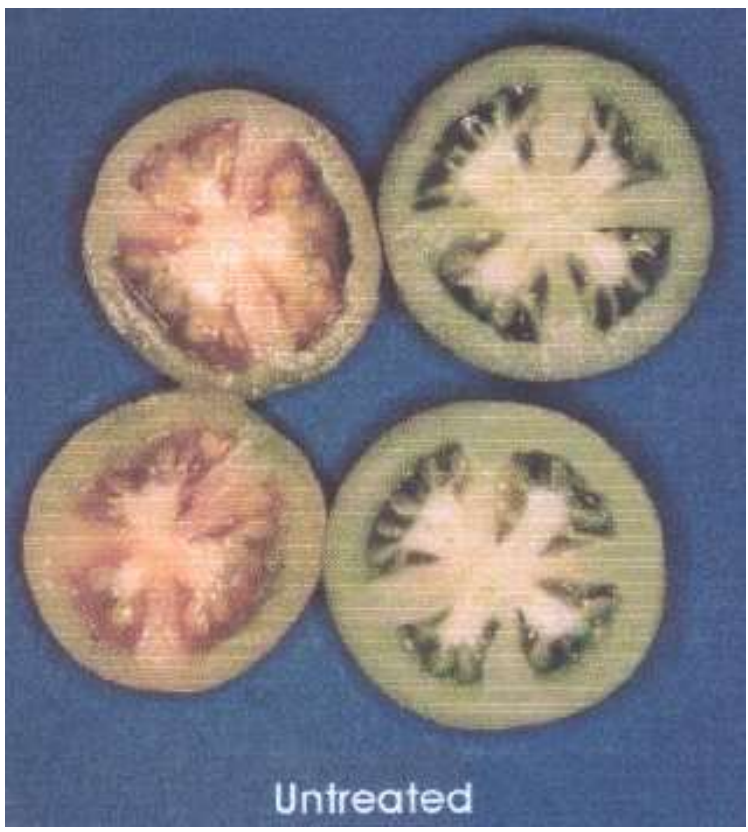

Figure 1b. Untreated Fruits 
Table. 1. Percent fruit set, percent fruit retention and number of days to fruit maturity of tomato (Improved Pope) as influenced by time and level of chlorophenoxyacetic acid (CPA) application

\begin{tabular}{llll}
\hline Treatments & $\begin{array}{l}\text { Fruit set } \\
(\%)\end{array}$ & $\begin{array}{l}\text { Fruit Retention } \\
(\%)\end{array}$ & $\begin{array}{l}\text { Days to } \\
\text { maturity }\end{array}$ \\
\hline Time of application & & & \\
At anthesis & $61.16 \mathrm{a}$ & 75.86 & 22.18 \\
One week after anthesis & $35.60 \mathrm{~b}$ & 78.03 & 22.26 \\
& & & \\
Level of CPA & $10.27 \mathrm{c}$ & $50.23 \mathrm{~b}$ & $26.96 \mathrm{a}$ \\
Control & $47.76 \mathrm{~b}$ & $82.08 \mathrm{a}$ & $21.62 \mathrm{~b}$ \\
25 ppm & $49.84 \mathrm{~b}$ & $83.44 \mathrm{a}$ & $21.56 \mathrm{~b}$ \\
50 ppm & $68.17 \mathrm{a}$ & $84.99 \mathrm{a}$ & $20.77 \mathrm{c}$ \\
75 ppm & $68.96 \mathrm{a}$ & $85.90 \mathrm{a}$ & $20.52 \mathrm{c}$ \\
$100 \mathrm{ppm}$ & & 3.61 & 1.56 \\
& 10.18 & & \\
\hline CV $(\%)$ & &
\end{tabular}

Table. 2. Fruit characteristics of tomato (Improved Pope) as influenced by time and rate of chlorophenoxyacetic acid (CPA) application

\begin{tabular}{|c|c|c|c|c|c|}
\hline Treatments & Fresh weight & Fruit siz & $(\mathrm{cm})$ & No of & $\%$ \\
\hline & (g/fruit) & Length & Diam. & $\begin{array}{l}\text { seeds } \\
\text { /fruit }\end{array}$ & $\begin{array}{l}\text { Parthe- } \\
\text { nocarpy }\end{array}$ \\
\hline Time of application & & & & & \\
\hline At anthesis & $34.37 b$ & $3.93 b$ & $3.06 \mathrm{~b}$ & 18.25 & 80 \\
\hline One week after anthesis & $41.87 \mathrm{a}$ & $4.45 \mathrm{a}$ & $3.71 \mathrm{a}$ & 18.43 & 80 \\
\hline Level of CPA & & & & & \\
\hline Control & $22.14 \mathrm{c}$ & $2.08 \mathrm{c}$ & $1.46 \mathrm{c}$ & $91.71 \mathrm{a}$ & $\mathrm{Ob}$ \\
\hline $25 \mathrm{ppm}$ & $41.78 b$ & $4.47 \mathrm{~b}$ & $3.90 \mathrm{~b}$ & $\mathrm{Ob}$ & $100 \mathrm{a}$ \\
\hline $50 \mathrm{ppm}$ & 41.79ab & $4.49 b$ & $4.08 \mathrm{~b}$ & $0 \mathrm{~b}$ & $100 \mathrm{a}$ \\
\hline $75 \mathrm{ppm}$ & $42.52 \mathrm{ab}$ & $5.19 a$ & $4.13 \mathrm{a}$ & $0 \mathrm{~b}$ & $100 \mathrm{a}$ \\
\hline $100 \mathrm{ppm}$ & $43.04 \mathrm{a}$ & $5.28 \mathrm{a}$ & $4.24 \mathrm{a}$ & $0 \mathrm{~b}$ & $100 \mathrm{a}$ \\
\hline $\mathrm{CV}(\%)$ & 6.65 & 6.67 & 8.21 & 8.05 & 0 \\
\hline
\end{tabular}

Treatment means in the same column within a sub-group designated by a common letter(s) and those without letter designation are not significantly different (DMRT, 5\% level). 
parthenocarpic fruits. Such effect of auxin on parthenocarpy phenomenon in tomatoes especially at high temperature was also reported byAVRDC (1988). It is probable that a high temperature fruit set occurred even without pollination and fertilization due to the exogenous application of auxin. According to Kuo et al. (1986) poor pollen and ovule development and style elongation caused by high temperature may be responsible for parthenocarpic fruit formation from heat stressed flowers in which fruit set and ovary growth have been induced by exogenous auxins. Furthermore, even if the development of pollen and ovule were normal, the rapid enlargement of the ovary caused by exogenous auxin may also prevent fertilization, thus resulting to parthenocarpy (Bangerth and Sjut, 1978).

\section{Yield and yield components}

Plants applied with CPA during flower anthesis produced more fruits, and had higher yield per plant as well as total fruit yield relative to those applied with CPA one week after anthesis (Table 3). The number and weight of nonmarketable fruits, however, were not affected by time of CPA application.

The number and weight of marketable and non-marketable fruits as well as the total fruit yield per plant and total yield in tons per hectare were dramatically improved by the application of CPA. The application of the CPA caused more than four times improvement in the aforementioned yield and yield component parameters of the crop, depending upon the concentration of the chemical. The number and weight of marketable fruits, fruit yield per plant and total yield did not significantly differ in plants applied with $75 \mathrm{ppm}$ and $100 \mathrm{ppm}$ CPA while no significant differences were observed on the number and weight of non-marketable fruits in plants applied with CPA at all levels. The improvement of the yield of the crop wth CPA application is attributed to the promotive effect of auxin on fruit set and development. Findings of this study lend support to the report of Thomas (1982) that an increase in fruit set is one of the key components deciding the final yield of the crop.

The time and level of CPA application had significant interaction effect on percent fruit set, fruit size, weight, and number of marketable fruits, fruit yield and total yield (Tables 4 and 5). Data indicate that the optimum concentration of CPA when applied at anthesis was $75 \mathrm{ppm}$. Increasing it further to $100 \mathrm{ppm}$ did not show any significant improvement in the aforementioned parameters. Although a similar trend was observed in plants applied with CPA one week after anthesis, improvement in the said parameters 
Table 3. Yield and yield components of tomato (Improved Pope) as influenced by time and rate of chlorophenoxyacetic acid (CPA) application

\begin{tabular}{|c|c|c|c|c|c|c|}
\hline \multirow{2}{*}{ Treatments } & \multicolumn{2}{|c|}{ No of fruits } & \multicolumn{2}{|c|}{ Wt. of fruits } & \multirow{2}{*}{$\begin{array}{l}\text { Fruit } \\
\text { Yield } \\
(\mathrm{kg} / \mathrm{plt})\end{array}$} & \multirow{2}{*}{$\begin{array}{l}\text { Total } \\
\text { Yield } \\
(\mathrm{t} / \mathrm{ha})\end{array}$} \\
\hline & $\begin{array}{l}\text { Market- } \\
\text { able }\end{array}$ & $\begin{array}{l}\text { Non- } \\
\text { Mar- } \\
\text { ketable }\end{array}$ & $\begin{array}{l}\text { Market- } \\
\text { able }\end{array}$ & $\begin{array}{l}\text { Non- } \\
\text { Mar- } \\
\text { ketable }\end{array}$ & & \\
\hline \multicolumn{7}{|l|}{ Time of Application } \\
\hline At anthesis & $41.60 \mathrm{a}$ & 13.65 & $1.81 \mathrm{a}$ & 0.37 & $2.18 \mathrm{a}$ & $22.32 \mathrm{a}$ \\
\hline 1 week after anthesis & $31.03 b$ & 13.34 & $1.17 \mathrm{~b}$ & 0.40 & $1.57 \mathrm{~b}$ & $13.55 \mathrm{~b}$ \\
\hline \multicolumn{7}{|l|}{ Level of CPA } \\
\hline Control & $10.09 \mathrm{~d}$ & $3.35 b$ & $0.24 \mathrm{c}$ & $0.92 \mathrm{a}$ & $0.32 \mathrm{c}$ & $3.00 \mathrm{c}$ \\
\hline $25 \mathrm{ppm}$ & $41.04 \mathrm{c}$ & $15.62 \mathrm{a}$ & $1.51 \mathrm{~b}$ & $0.47 \mathrm{~b}$ & $1.92 b$ & $16.04 \mathrm{~b}$ \\
\hline $50 \mathrm{ppm}$ & $42.32 \mathrm{bc}$ & $16.63 \mathrm{a}$ & $1.42 \mathrm{~b}$ & $0.46 \mathrm{~b}$ & $1.87 \mathrm{~b}$ & $17.45 \mathrm{~b}$ \\
\hline $75 \mathrm{ppm}$ & 43.43ab & $15.49 \mathrm{a}$ & $2.16 \mathrm{a}$ & $0.47 \mathrm{~b}$ & $2.63 \mathrm{a}$ & $27.90 \mathrm{a}$ \\
\hline $100 \mathrm{ppm}$ & $44.69 \mathrm{a}$ & $16.48 \mathrm{a}$ & $2.18 \mathrm{a}$ & $0.52 b$ & $2.67 \mathrm{a}$ & $25.00 \mathrm{a}$ \\
\hline$\overline{\mathrm{CV}(\%)}$ & 3.45 & 9.71 & 6.65 & 12.19 & 6.64 & 12.86 \\
\hline
\end{tabular}

except fruit weight, length and diameter with increase in the concentration of the chemical were significantly lesser.

\section{Fruit quality}

No significant differences were observed among the different treatments in terms of fruit quality. Peel color development, visual quality rating, firmness and weight loss during storage at ambient room temperature of fruits from plants applied with different levels of CPA at anthesis and one week after anthesis were not significantly different from the control. Fruits in all treatments attained the full ripe stage (C16) after 12-14 days and had a postharvest life of 14-15days (Table 6). The results suggest that chlorophenoxyacetic acid can be applied to increase fruit set and yield of tomato without affecting the quality of the fruits. 
Table 4. Interaction effect of time and level of chlorophenoxyacetic acid application on the percent fruit set and fruit size of tomato

\begin{tabular}{lllll}
\hline Treatments & $\begin{array}{c}\text { Fruit Set } \\
(\%)\end{array}$ & $\begin{array}{c}\text { Weight } \\
(\mathrm{g})\end{array}$ & $\begin{array}{c}\text { Length } \\
(\mathrm{cm})\end{array}$ & $\begin{array}{c}\text { Diameter } \\
(\mathrm{cm})\end{array}$ \\
\hline
\end{tabular}

CPA applied at anthesis

$\begin{array}{lllll}\text { Control } & 10.34 \mathrm{e} & 22.40 \mathrm{~d} & 2.07 \mathrm{~d} & 1.47 \mathrm{~d} \\ 25 \mathrm{ppm} & 59.86 \mathrm{~b} & 38.49 \mathrm{c} & 3.88 \mathrm{c} & 2.94 \mathrm{c} \\ 50 \mathrm{ppm} & 59.46 \mathrm{~b} & 36.36 \mathrm{c} & 4.04 \mathrm{c} & 3.34 \mathrm{c} \\ 75 \mathrm{ppm} & 81.06 \mathrm{a} & 38.96 \mathrm{~b} & 4.92 \mathrm{~b} & 3.94 \mathrm{~b} \\ 100 \mathrm{ppm} & 82.90 \mathrm{a} & 39.22 \mathrm{~b} & 4.71 \mathrm{~b} & 3.99 \mathrm{~b}\end{array}$

CPA applied 1 week after anthesis

\begin{tabular}{lllll} 
Control & $9.40 \mathrm{e}$ & $21.89 \mathrm{~d}$ & $2.10 \mathrm{~d}$ & $1.44 \mathrm{~d}$ \\
$25 \mathrm{ppm}$ & $35.91 \mathrm{~d}$ & $47.27 \mathrm{a}$ & $4.27 \mathrm{~b}$ & $3.94 \mathrm{~b}$ \\
$50 \mathrm{ppm}$ & $36.32 \mathrm{~d}$ & $47.23 \mathrm{a}$ & $4.94 \mathrm{~b}$ & $4.50 \mathrm{ab}$ \\
$75 \mathrm{ppm}$ & $40.94 \mathrm{c}$ & $48.81 \mathrm{a}$ & $5.46 \mathrm{a}$ & $4.83 \mathrm{a}$ \\
$100 \mathrm{ppm}$ & $43.42 \mathrm{c}$ & $49.12 \mathrm{a}$ & $5.47 \mathrm{a}$ & $4.85 \mathrm{a}$ \\
\hline
\end{tabular}

Treatment means within a column designated by a common letter(s) are not significantly different (DMRT, 5\% level).

Table 5. Interaction effect of time and level of chlorophenoxyacetic acid application on the number and weight of marketable fruits and total yield of tomato

\begin{tabular}{lllll}
\hline Treatments & $\begin{array}{l}\text { Weight of } \\
\text { Marketable } \\
\text { Fruits/plant }\end{array}$ & $\begin{array}{l}\text { No. of } \\
\text { Marketable } \\
\text { Fruits/plant }\end{array}$ & $\begin{array}{l}\text { Total fruit } \\
\text { Yield } \\
(\mathrm{kg} / \mathrm{plant})\end{array}$ & $\begin{array}{l}\text { Total fruit } \\
\text { Yield } \\
(\mathrm{t} / \mathrm{ha})\end{array}$ \\
\hline CPA applied at anthesis & & & & \\
Control & $0.25 \mathrm{~d}$ & $10.10 \mathrm{e}$ & $0.33 \mathrm{e}$ & $4.60 \mathrm{e}$ \\
$25 \mathrm{ppm}$ & $1.76 \mathrm{~b}$ & $48.04 \mathrm{~b}$ & $2.25 \mathrm{~b}$ & $34.20 \mathrm{~b}$ \\
$50 \mathrm{ppm}$ & $1.74 \mathrm{~b}$ & $48.22 \mathrm{~b}$ & $2.09 \mathrm{c}$ & $30.10 \mathrm{~b}$ \\
$75 \mathrm{ppm}$ & $2.54 \mathrm{a}$ & $50.18 \mathrm{~b}$ & $3.19 \mathrm{a}$ & $48.50 \mathrm{a}$ \\
$100 \mathrm{ppm}$ & $2.78 \mathrm{a}$ & $51.57 \mathrm{a}$ & $3.24 \mathrm{a}$ & $46.90 \mathrm{a}$ \\
& & & & \\
CPA applied 1 week after anthesis & & & \\
Control & $0.23 \mathrm{~d}$ & $10.19 \mathrm{e}$ & $0.32 \mathrm{e}$ & $3.60 \mathrm{e}$ \\
$25 \mathrm{ppm}$ & $1.17 \mathrm{c}$ & $34.04 \mathrm{~d}$ & $1.59 \mathrm{~d}$ & $17.90 \mathrm{~d}$ \\
$50 \mathrm{ppm}$ & $1.18 \mathrm{c}$ & $36.41 \mathrm{c}$ & $1.65 \mathrm{~d}$ & $15.40 \mathrm{~d}$ \\
$75 \mathrm{ppm}$ & $1.55 \mathrm{~b}$ & $36.67 \mathrm{c}$ & $2.02 \mathrm{c}$ & $25.20 \mathrm{c}$ \\
$100 \mathrm{ppm}$ & $1.72 \mathrm{~b}$ & $37.82 \mathrm{c}$ & $2.27 \mathrm{~b}$ & 25.90 \\
\hline Treatment means within a column designated by a common letter(s) are not significantly \\
different (DMRT, 5\% level).
\end{tabular}


Table 6. Number of days to CI 6 and VQR 3 of tomato (Improved Pope) as influenced by time andlevel of chlorophenoxyacetic acid (CPA) application

\begin{tabular}{lcc}
\hline Treatments & $\begin{array}{c}\text { Days to Color Index 6 } \\
\text { (CI 6) }\end{array}$ & Days to VQR 3 \\
\hline Time of Application & 12.50 & 15.02 \\
At anthesis & 12.59 & 14.99 \\
1 week after anthesis & & \\
& & \\
Level of CPA & 12.14 & 15.00 \\
Control & 12.21 & 15.05 \\
$25 \mathrm{ppm}$ & 12.17 & 15.05 \\
$50 \mathrm{ppm}$ & 12.15 & 15.10 \\
$75 \mathrm{ppm}$ & 12.20 & 15.09 \\
$100 \mathrm{ppm}$ & & 11.09 \\
\hline $\mathrm{CV}(\%)$ & 8.52 & \\
\hline
\end{tabular}

\section{CONCLUSIONS}

Results of this study show that the application of chlorophenoxyacetic acid (CPA) at 25-100 ppm particularly during anthesis enhanced fruit set and consequently improved the yield and yield components of the crop. In addition, the chemical caused the production of parthenocarpic or seedless fruits. The optimum concentration of the chemical was $75 \mathrm{ppm}$.

\section{LITERATURE CITED}

ABIT, A. E. 1981. Effects of 2,4-dichlorophenoxyacetic acid on fruit set and yield of tomato (Lypersicon esculentum Mill.) Graduate Thesis. Leyte Institute of Technology. Tacloban City, Phils.

ARUMIN, Y. K., OSHIMA, and K. SHUDO. 1985. Evolution of novelurea type cytokinin: Horticultural uses of forchlorfenuron. Acta Horticulturae:394:75-79.

ASIAN VEGETABLE RESEARCH AND DEVELOPMENT CENTER.1988. AVRDC Progress Report 1988. Shanhua, Taiwan.

ASIAN VEGETABLE RESEARCH AND DEVELOPMENT CENTER.1988. AVRDC Progress Report 1991. Shanhua, Taiwan.

ASIAN VEGETABLE RESEARCH AND DEVELOPMENT CENTER.1988. AVRDC Progress Report 1995. Shanhua, Taiwan. 
BANGERTH, F. and V. SJUT. 1978. Induced parthenocarpy - a tool for investigating hormone-regulated physiological processes in fruits. Acta Horticulturae. 80:169174.

DEL ROSARIO, R. P., R. M. ABILAY and E. R. B. PANTASTICO. 1977. Fruit set and development of lanzones sprayed with some growth regulators. Philippine Agriculturist. 60:1977.

GOODWIN, P. B.. 1978. Phytohormones and fruit growth. In: Phytohormones and related compounds - A Comprehensive Treatise. Vol. II. D. S. Letham, P. B. Goodwin and T. J.V. Higgins (eds) Elsevier/North-Olland Biomedical Press. Amsterdam, Oxford, New York. p. 175-214.

JOSEPH, C. B.and K. V. PETER. 1980. Effect of 2,4-D on fruit yield, leaf area and flower characters in tomato. Journal of Horticultural Science, 55(1):41-43.

KINET, J. M., D. HURDEBISE, A. PARAMENTIER and R. STAINIER. 1978. Promotion of inflorescence development by growth substance treatments to tomato plants grown in insufficient light condition. Jour. of the Amer. Soc. for Hort. Sci. 103:724729.

KUO, O. G., H. M.CHAN and H. C. CHEN. 1986. Plant hormones in tomato fruit set and development. In: Plant Growth Regulators in Agriculture. Food and Fertilizer Technology Center for the Asian and the Pacific Region, Taiwan, Republic of China. P 56-59.

PHIL. STATISTICAL YEARBOOK. 1999. The National Statistics Information Center, Makati City, Philippines. pp.5.

PICKEN, A. J. F. 1984. A review of pollination and fruit set in the tomato (Lypersicon esculentum Mill.) Journal of Horticultural Science. 59:1-3.

STAHL, W. and H. SIES. 1996. Lycopene: A biological important carotenoid for humans? Archives of Biochemistry and Biophysics. 336(1)-1-9.

THOMAS, T. H. 1982. Vegetable crops. In: Plant growth regulators - potential and practice. The Lavenham Press Ltd. Suffolk, U. K. p. 109-122.

WEAVER, R. J. 1972. Plant Growth Substances in Agriculture. W. H. Freeman and Company, San Francisco, USA. pp. 222-250. 